\title{
Three Characters Moulded in Music Education
}

\author{
${ }^{\bowtie}$ Tyas Kartiko Sutawi
}

\author{
Eduacational Research and Evaluation Program, \\ Universitas Negeri Yogyakarta, Indonesia
}

Received: June 10, 2018. Revised: October 8, 2018. Accepted: December 19, 2018

\begin{abstract}
Character building is an emerging issue in the education field. Character building in school is integrated through a learning process in each existing subject. Music education as one of the subjects in school, could mean to students' character building. It could be done through various musical activities which can be experienced directly by the students, one of them is an ensemble. The goal of this article is to reveal characters that could be developed through music education, especially ensemble. This research was done in a public senior high school in Yogyakarta by choosing three samples based on Proportional Stratified Random Sampling technique. The data was gathered by using questionnaire based on Exploratory Factor Analysis and Confirmatory Factor Analysis techniques. Reliability was counted by using Cronbach Alpha and Variance Reliability formula. Also, descriptive quantitative is used as a data analysis technique in this research. The result shows that there are three characters molded through music education at school, they are "rasa" sensitivity, creativity and respect.
\end{abstract}

Keywords: Music Education; Ensembles; Creativity; Respect

How to Cite: Sutawi, T. K. (2018). Three Characters Moulded in Music Education. Harmonia: Journal of Arts Research And Education, 18(2), 200-207.

\section{INTRODUCTION}

Music could mean to embed value and ideology from a nation (Wai \& Wing, 2004). It could be done by doing various musical activities like singing or playing instruments (Hash, 2014). Music education is seen as the right means to support character building because music has many positive impacts on children (Mudjilah, 2012). A relating character with musical activities could draw students' interest more so that it becomes more memorable (Justina \& $\mathrm{Wu}, 2011)$. More than that, in music education, character plays an important role as the determinant of learning success. A character is not only what is written on curriculum, but more about students' attitude in playing music like responsibility in what they are learning, desire to always practice, willingness, interest, readiness, energetic and creative (Berger, 2014).

Music education process contains an interaction process which covers perception or "rasa", transforming, expressing and appreciating (Astuti, 2010). Perception activity is a process to understand and do art. Transforming process is a creative process which contains thinking activity, feeling, imagination, intuition, and problemsolving. Expressing activity is a process to express thoughts, feelings, and understanding through music, while appreciation is a reflective process, analysis, critique and

\footnotetext{
${ }^{\boxplus}$ Corresponding author: Jl. Colombo, Depok Sleman 55281

E-mail: kartikot@yahoo.co.id
} 
value art through music.

A teacher could embed character through studying song's meaning or "students research song dealing with celebration, community, respect or individuality..study the lyrics"(Petersen, 2012) or by using other activities like playing music together or what is a so-called ensemble. This learning in a form of the group enables students to explore "rasa", attitude, and strategy in solving a problem just like in learning about the value (Joyce, Calhoun \& Hopkin, 2009). The ensemble is meant for students to have musical experience. Hincley (see Mark (2010) stated that "the middle school might also require short six-week rotations into vocal and instrumental experiences to stimulate interest in joining the regular ensembles".

The ensemble is done based on difficulty level and musicality style. According to those, some important aspects from designing ensemble activities are (considering) series of knowledge and skills mastered by the students. In preparation, a teacher has to consider students' musical skills and knowledge to be able to choose the material to practice. The material chosen is not only songs that can be played easily by the students, but also the song that meets the requirements of the good musical standard. According to Mark (2010) "this music curriculum should allow students to grow musically and artistically during the school years, and prepare them to participate in music for a lifetime". Even though it seems like not all students have a dream to be a musician, it can stimulate balanced musical sides (artistic). Ensemble itself could train students to be able to work together with friends and listen to each other so that it can support social skills.

Through art and cultural education, students learn to think democratically and could express themselves freely. Students will feel happy when they could express themselves by playing music. Education process like this will be more conducive because students will be more autonomous and free in expressing themselves. Be- sides, students will be more responsible to imaginatively decide the arrangement and design of the show autonomously (Gilbert, 2016). Art education determines students' sensitivity in giving expression and respond in life. It also gives a chance for students to know and assess academic, social, emotional, cultural, moral, and other personal skills for spiritual development.

Character building is a continuous activity containing components that can support each other. Astuti (2011) stated that there are some components that could support the success of character building, especially in art education, they are curriculum as the direction of character building, teachers as moral agent, the development of art materials that educate students, the development of character building's method based on art, the development of character building based on art process, and the development of character building's evaluation based on art.

\section{METHOD}

Sample selection was done by grouping 14 schools that conduct music education in Yogyakarta into three parts, they are schools with high, medium and low rank. The data related to the rank was taken from schools rank data based on the grades on National Exam in the school year 2016/2017 from Education Board of Yogyakarta. From each group, the researcher chose one school by using a random sampling technique, until three sample schools were chosen. Meanwhile, the sampling for students was done by using proportional stratified random sampling by using Slovin formula (Isaac, 1984) with 354 students as a total sample of students class VII. Exploratory Factor Analysis was done on Outcomes variable with 17 questions on the questionnaire. The analysis was then continued by using Confirmatory Factor Analysis.

\section{RESULTS AND DISCUSSION}

Through a validity test by using Exp- 
loratory Factor Analysis, the value of $\mathrm{KMO}$ and sig Bartlett's Test were obtained and summarized in Table 1.

Table 1. KMO and sig Barlett's Test value in EFA

Total Items KMO Value Sig Bartlett's Test Value

$17 \quad 0,889 \quad 0,00$

Based on Table 1, the KMO value is 0,889 which is greater than 0,5 . It shows that every variable has strong relations and meets the total sample so that Exploratory Factor Analysis can be done. Next, the value of sig is $0,000<0,05$, which means that there is a correlation between the tested variables. With that result, it can be concluded that the variable and sample used were possible to be analyzed more.

Next, the value of anti-image can be seen to determine the items that can be used. If that value is more than 0,5 , the item can be used. However, if the value is less than 0,5 , the item should not be used. The summary of anti-image value is shown in Table 2.

Based on Table 2, it is known that all MSA values for every variable are more than 0,5 so that the analysis of all items can be continued because those items still can be predicted and can be analyzed. Besides, communality value can also be seen in every item. Communalities value explains how influential the formed factor in explaining the variable. The summary of communalities value can be seen in Table 3 .

Next step is determining the cluster based on Eigenvalue. The value of Eigenvalue is used to see how many clusters/ components formed. The number of those components/clusters can be seen from the total value of Eigenvalue which is greater than 1. Below is the summary of Eigenvalue.

Table 4. Summary of Eigenvalues EFA Outcomes variable

\begin{tabular}{cccc}
\hline \multirow{2}{*}{ Component } & \multicolumn{3}{c}{ Eigenvalues Initial } \\
\cline { 2 - 4 } & Total & $\begin{array}{c}\text { Variancei } \\
(\%)\end{array}$ & $\begin{array}{c}\text { Cumulative } \\
(\%)\end{array}$ \\
\hline 1 & 6,79 & 35,760 & 35,760 \\
2 & 2,359 & 13,878 & 49,638 \\
3 & 1,188 & 6,986 & 56,624 \\
\hline
\end{tabular}

From Table 4, it shows that there are 3 clusters formed from 17 items on a questionnaire with $56,624 \%$ as the cumulative contribution value. Thus, it can be conclu-

Table 2. Correlation Value of Anti Image in EFA

\begin{tabular}{cccccc}
\hline Items & $\begin{array}{c}\text { Anti Image's } \\
\text { Value }\end{array}$ & Items & $\begin{array}{c}\text { Anti Image's } \\
\text { Value }\end{array}$ & Items & $\begin{array}{c}\text { Anti Image's } \\
\text { Value }\end{array}$ \\
\hline B1 & 0,892 & C2 & 0,910 & D2 & 0,798 \\
B2 & 0,893 & C3 & 0,895 & D3 & 0,797 \\
B3 & 0,934 & C4 & 0,886 & D4 & 0,819 \\
B4 & 0,907 & C5 & 0,891 & D5 & 0,883 \\
B5 & 0,926 & C6 & 0,931 & D6 & 913 \\
C1 & 0,882 & D1 & 0,880 & & \\
\hline
\end{tabular}

Table 3. Communalities Value in EFA Outcomes Variable

\begin{tabular}{ccccccccc}
\hline Item & Initial & Extraction & Item & Initial & Extraction & Item & Initial & Extraction \\
\hline B1 & 1.00 & 0,616 & C2 & 1.00 & 0,661 & D2 & 1.00 & 0,482 \\
B2 & 1.00 & 0,508 & C3 & 1.00 & 0,618 & D3 & 1.00 & 0,723 \\
B3 & 1.00 & 0,423 & C4 & 1.00 & 0,647 & D4 & 1.00 & 0,627 \\
B4 & 1.00 & 0,632 & C5 & 1.00 & 0,633 & D5 & 1.00 & 0,562 \\
B5 & 1.00 & 0,642 & C6 & 1.00 & 0,537 & D6 & 1.00 & 0,407 \\
C1 & 1.00 & 0,588 & D1 & 1.00 & 0,319 & & & \\
\hline
\end{tabular}


ded that all items can be analyzed further using factor analysis with extraction and rotation methods using varimax. The result can be seen in Table 5 .

Table 5. Rotated Component Matrix Outcomes

\begin{tabular}{cccc}
\multicolumn{4}{c}{ Variable } \\
\hline \multicolumn{4}{c}{ Component } \\
\hline B1 & 1 & 2 & 3 \\
B2 & .022 & .783 & .052 \\
B3 & .102 & .671 & .217 \\
B4 & .376 & .559 & .224 \\
B5 & .526 & .702 & .001 \\
C1 & .728 & .194 & .060 \\
C2 & .587 & .563 & .144 \\
C3 & .753 & .021 \\
C4 & .721 & .341 & .220 \\
C5 & .576 & .544 & .068 \\
C6 & .609 & .297 & .279 \\
D1 & .340 & -.015 & .451 \\
D2 & .200 & .024 & .665 \\
D3 & -.008 & .182 & .830 \\
D4 & -.032 & .117 & .782 \\
D5 & .107 & .104 & .735 \\
D6 & .308 & .092 & .551 \\
\hline Extraction Method: Principal Com- \\
ponent Analysis. Rotation Method: \\
Varimax with Kaiser Normalization.
\end{tabular}

In Table 5, all loading factor values meet the required criterion which is $\geq 0.4$. There are three clusters formed from 17 questions. They are (1) component 1 which consists of 6 items, included to the creative group, (2) component 2 which consists of 5 items, included to "rasa" sensitivity group, and (3) component 3 which consist of 6 items, included the respecting group.

According to the clusters obtained from Exploratory Factor Analysis, the analysis can be continued by using Confirmatory Factor Analysis (CFA). The second CFA analysis was done on Outcomes variable which measures the character of students. The analysis result shows Chi-Square value represented by Satorra-Bentler Scaled Chi-Square $=0,0$ with P-value of 1.00 and Root Mean Square Error of Approximation $($ RMSEA $)=0,00$. Here is the standardized solution of music education implementation in Junior High School in Yogyakarta.

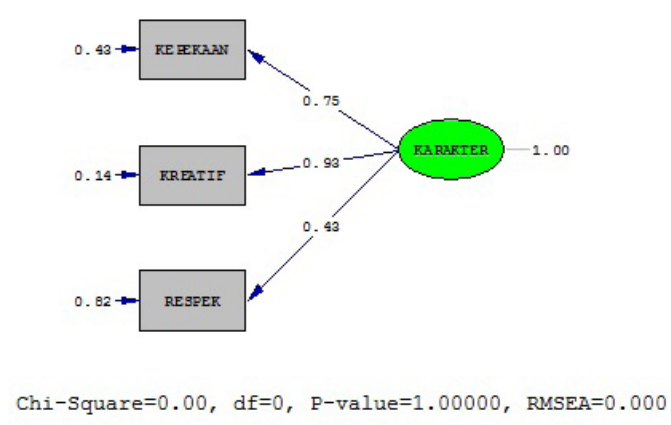

Figure 1. Standardized Solution Model OutcomesVariable

Referring to $\mathrm{p}$-value result from Satorra-Bentler Chi-Square of $1>0,05$, it can be concluded that the data fit the model. This also applies to RMSEA value of $0,00<$ 0,08 which shows that model matches are acceptable. Thus, referring to the matching value of each parameter, this model is the right fit. Below is the Figure of Outcomes variable model of music education implementation seen from T-values.

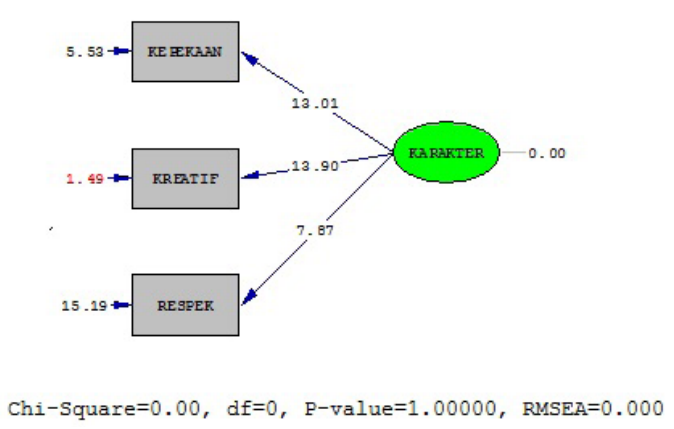

Figure 2. T -Value Model Outcomes variable

The summary and conclusion of standardized loading factors and $t$-value to see item validity in each variable are shown in Table 6.

Reliability on the questionnaire was counted by using Alpha Cronbach formula for EFA, also Variance Extract (VE) and Construct Reliability (CR) for CFA. This test was used to count the reliability of each component and total which refers to EFA and CFA value obtained. The result of coefficient reliability construct for EFA 
Table 6. CFA Summary

\begin{tabular}{cccccc}
\hline $\begin{array}{c}\text { Item } \\
\text { Code }\end{array}$ & $\begin{array}{c}\text { Standardized Loading } \\
\text { Factors (SLF) } \geq 0,3\end{array}$ & $\begin{array}{c}\text { Standard } \\
\text { Errors }\end{array}$ & $\begin{array}{c}\text { t-value } \geq \\
1,96\end{array}$ & $\begin{array}{c}\text { Error } \\
\text { Variance }\end{array}$ & Result \\
\hline CV & 0,75 & 0,43 & 13,01 & 5,53 & $\begin{array}{c}\text { Good } \\
\text { Validity } \\
\text { TS }\end{array}$ \\
TS & 0,93 & 0,14 & 13,90 & 1,49 & $\begin{array}{c}\text { Validity } \\
\text { Good } \\
\text { Ralidity }\end{array}$ \\
\hline
\end{tabular}

Notes: CV : Creative TS: "rasa" Sensitivity RS: Respect

Table 7. Summary of Coefficient Reliability EFA

\begin{tabular}{|c|c|c|c|c|}
\hline Component & $\begin{array}{l}\text { Cronbach's Alpha } \\
\text { Coefficient Per } \\
\text { Indikator }\end{array}$ & $\begin{array}{l}\text { Cronbach's Al- } \\
\text { pha Coefficient } \\
\text { in General }\end{array}$ & $\begin{array}{l}\text { Construct } \\
\text { Reliability }\end{array}$ & Result \\
\hline Kepekaan Rasa & 0,788 & & & Reliable \\
\hline Kreatif & 0,857 & 0,886 & 0,76 & Reliable \\
\hline Respek & 0,776 & & & Reliable \\
\hline
\end{tabular}

is summarised in Table 29.

Based on Table 3, it can be concluded that questionnaire used in the research was reliable so that the instrument can be used to do another measurement on the same type of objects because it has coefficient reliability $>0,7$

Based on Exploratory Factor Analysis, there are three groups of characters in music education, they are "rasa" sensitivity, creativity and respect. These three groups were then analyzed further using Confirmatory Factor Analysis. From it, a fit model was obtained. It shows that the three character groups are the outcome of music education, especially ensemble, they are "rasa" sensitivity, creativity and respect.

Weiss (2006) explains that "rasa" is something complex, which related to ears and heart. "rasa" could mean a harmony between musicality, thought and body. "Rasa" is also related to expressing music. Thus, "rasa" sensitivity also means being sensitive to feeling, "rasa" or emotion. All those "rasa" elements can be realized using an expression, which also included in musical activities in class (Fautley \& Savage, 2011). "Rasa" sensitivity meant here is the sensitivity of beauty which is attributed to education needs, or in the art field. It is in line with the purpose of Art \& Culture subject, that is to develop an aesthetic person, critical attitude, appreciation and creative attitude. According to Dewantara (1961), children need to get used to the characters of beauty so that they can be persons who are beauty educated. Educating children to get used to the characteristics of beauty means that educating children about discipline. Besides, embedded the "rasa" of aesthetic cannot be taught mathematically to students. It should be done through the introduction of all forms of art and example observed especially how the closest environment gives appreciation to all kinds of beauty. The music itself is used to train/ educate feeling through listening which has influence deeper to feeling than seeing (Dewantara, 1961). Being sensitive to beauty is beneficial in the living process, which is to build someone's character who likes to socialize and talk beautifully (Pamadhi, 2012).

From all explanations above, it can be seen that "rasa" sensitivity meant will go in line with what is learned in music education at school. Aesthetic "rasa" sensitivity will automatically intersect with values obtained by students in the process of constructing knowledge and their experience in appreciation making in class. The 
orientation of "rasa" sensitivity is music theory as well as experience in playing music in class. Because of that, students have to be the first subject in doing music education so that they can have direct experience (Burke, 2014). It can be seen from the result of music education at school. The results are students can have musical sensitivity, like listening sensitivity either to tone, rhythm, dynamics and timbre as basic elements of music. That musical sensitivity is correlated significantly to children's social intelligence aspect (Djohan, 2009). Thus, it can be concluded that "rasa" sensitivity has some indicators. Some of the indicators are having music preference in a certain situation, showing emotional tendency which is delivered through tempo and dynamics in arrangement result, trying to show harmonic show, both in show concept or an arrangement, being expressive in listening to music, and respecting other people's music.

Composing through art is such an important and fundamental form of creativity (Wright, 2010). Music can give contribution in helping children to be more creative (Fitzpratick, 2013). To increase creativity in music education at school, the learning should be based on creative activity as well. Besides, a teacher needs to explore learning activity from many sources, because teacher's perception determines what kind of creative musical activity that will be done by the students (Odena \& Welch, 2009).

To support all aspects of students' development, a teacher needs to make students accustomed to having created character through arranging or composing music in class (Tomlinson, 2012). This can be done by gaining information or knowledge first about basic music theory, arrangement and composition as students' basic to be able to develop creativity in processing sound and show. Besides, research result from Raymond, MacDonald \& Miell (2000:58-68) shows that social environment, including communication between friends can influence students' creativity, where students feel more comfortable in being creative in the environment that they are familiar with. Students tend to be free in doing musical creation on time with a more satisfying result (Black, 2011). The music teacher can consider expanding the learning so that students can have more time to respond to musical activity in class. A teacher should push students to be creative in any way using all genres and some instruments (Kiehn, 2007). There are some indicators from a creative character they are able to arrange a new idea, spread new creation to a stranger, able to solve problems, get used to making one idea, have high imagination, and able to create new work or, especially in a music learning process, able to do some arrangement on a work.

The last character is respect. Respect is an attitude and action that push somebody to produce something useful in society, acknowledge and honor other people's success. Cranor (1975) said that there is a certain reason why somebody gives respect to others. The reason can be sympathy, or positive view about someone's behavior or attitude. Respect does not mean being obedient, but more than that, respect means showing honor (Dimerman, 2009). Honor is giving appreciation, to him/herself, others, or the environment. So it can be concluded that respect is giving appreciation to him/herself, others and an environment in the process of maintaining a balance between the obligation to finish responsibility and ability to fulfill personal needs, by not breaking other's rights.

To work in a musical group, respect and trust are needed, also the ability to negotiate and compromise. These characters are needed to support a conducive environment while the learning process is happening. Respect can help students to work together well. Music education gives chance to students to socialize in an activity which is done together and also needs togetherness, honor, and understanding from each member to another through ensemble activity.

Respect is related to social relation- 
ships among humans. Hogene, Oers \& Diestra (2014) explains that music education can influence children's socioemotional ability. According to Dora and Poetiray (2012), the process of art making which related to culture, helps students to mold their characters because there is value transmission process happens in the learning to the young generation who needs mutual respect attitude in life. In the learning activity, respect character can be embedded through gaining knowledge about how to appreciate the uniqueness of every kind of music, either from musicality or from a performance. Besides, this character can be embedded through practice playing ensemble, either one kind or mixed ensemble.

Respect character can be exposed through honoring friends or self in every learning activity. Some indicators of respect are able to respect him/herself by not doing bad actions like cheating and etc, able to honor others by always be nice to friends and teacher, able to accept agreement even though he/she has a different opinion, also able and willing to work with anybody even though they have diverse backgrounds, views, and beliefs.

\section{CONCLUSION}

Music education is a medium to build students' characters. An ensemble is one form of musical activity which not only liked by students, but also can build students' character. Through the research result, there are three characters formed as the result of ensemble activity in music education. The characters are "rasa" sensitivity, creativity and respect. Those three characters are basic characters that students need to have related to music education. This research result can be a reference for a teacher to be able to increase students' outcome quality related to character building.

\section{REFERENCES}

Astuti, K. S. (2010). Shaping Morality
Through Music Learning in Formal Schools in Indonesia: An Evaluation Study. In The Fifth Conference of The Asia Pacific Network for Moral Education: Moral Education in Asia's Globalizing Societies, Concepts and Practices. Nagasaki: Nagasaki University.

Astuti, Kun Setyaning. (2011). Pendidikan Karakter Dalam Perspektif Teori dan Praktik. Yogyakarta: UNY Press.

Berger, K. (2014). Character Development Through Music - Dealing with Failure and Frustration, and the Keys to Success. Retrived from www.NorthStateParentMagazine.com.

Black, Christina. (2011). Creative Thinking in a General Music Classroom: Process, Meaning, and Collaboration Among Second Graders. The Pennsylvania State University May 3, 2011. Retrived from https:// scholarsphere.psu.edu/downloads/ x346d674g.

Burke, Harry. (2014). Influential Pioneers of Creative Music Education in Victoria, Australia. Australian Journal on Music Education, 2014(2), 23-35.

Cranor, C. (1975). Toward a Theory of Respect for Persons. American Philosophical Quarterly, 12(4), 303-319.

Dewantara, K. H. (1961). Pendidikan. Yogyakarta: UST-Press

Dimerman, Sara. (2009). Character is The Key: How to Unlock the Best in Our Children and Ourselves. Canada: John Wiley \& Sons Canada, Ltd.

Djohan. (2009). Kemampuan Musikalitas Sebagai Sarana Pengembangan Keterampilan Sosial. Jurnal Penelitian dan Evaluasi Pendidikan,1, 124-131.

Dora, Purnama Esa and Poetiray, Maria Suzanna G. (2012). The Role Of Basic Design Course in the Introduction and Development of Local Culture Values. Jurnal Pendidikan Karakter, 2(1), 2934.

Fautley, Martin \& Savage, Jonathan. (2011). Cross-Curricular Teaching and Learning in The Secondary School. Oxon: Routledge.

Fitzpatrick, Frank. (2013). Why Music, Part 
6: Music and Creativity. Retrieved from http://www.huffingtonpost. com/frank-fitzpatrick/music-andcreativity_b_2253464.html.

Gilbert, Danni. (2016). Curious, Collaborative, Creativity. Music Educators Journal, 103(2), 27-34.

Hash, Phillip M. (2014). Character Development and Social Reconstruction in Music Education at the turn of the Twentieth Century. Michigan: Grand Rapids.

Hogene, M., Oers, B. \& Diekstra, R. F. W. (2014). The Impact of Music on Child Functioning. The European Journal of Social \& Behavioural Sciences. DOI: http:/ / dx.doi.org/10.15405/ejsbs.135

Isaac, Stephen \& Michael, W. B. (1984). Handbook in Research and Evaluation. San Diego: Edits.

Joyke, B., Calhoun, E., \& Hopkins, D. (2009). Models of Learning Tools for Teaching. USA: Two Penn Plaza. Hal 108.

Justina \& Wu. (2011). Character Building Through Music. Canada: The Curriculum Foundation.

Kiehn, Mark. (2007). Creative Thinking: Music Improvisational Skills Development among Elementary School Students. University of WisconsinGreen Bay. Retrieved from http:// www.scientificjournals.org/journals2007/articles/1213.pdf.

Mark, Michael L and Patrice Madura. (2010). Music Education in Your Hands: An Introduction for Future
Teacher. New York: Routledge.

Mudjilah, H. S. (2012). Membangun Karakter Bangsa Melalui Kemampuan Musikal Anak. In Konferensi Ilmiah Nasional "Asesmen dan Pembangunan Karakter Bangsa" UNESA.

Odena, O. \& Welch, Graham. (2009). Generative Model on Teacher Thinking on Musical Creativity. Psychology of Music, 4(2), 416-442.

Pamadhi, H.. (2012). Pendidikan Seni (Hakikat Kurikulum Pendidikan Seni, Hanitus Seni, dan Pengajaran Seni Anak). Yogyakarta: UNY Press.

Petersen, K. (2012). Activities for Building Character and Social Emotional Learning Grades 6-8. Minneapolis: Free Spirit Publishing Inc.

Raymond, A.R. MacDonald \& Dorothy Miell. (2000). Creativity and Music Education: The Impact of Social Variables. International Journal of Music Education, 36(1), 58-68. DOI: https:// doi.org/10.1177/025576140003600107

Tomlinson, Michelle. (2012). Transformative Music Invention. Australian Journal of Music Education, 1(1), 42-56.

Wai, C. H. \& Wing, Wah Law. (2004). Values, Music and Education in China. Music Education Research, 6(2), 149-168. DOI: https://doi. org/10.1080/1461380042000222564

Weiss, Sarah. (2006). Listening to an Earlier Java. Netherlands: KITLV Press.

Wright, S. (2010). Understanding Creativity in Early Childhood. Great Britain: SAGE Publications, Inc. 